\title{
GAYA KOMUNIKASI PS. CHRISTOFER TAPIHERU DALAM MEMBENTUK PERSONAL BRANDING
}

\author{
Ester Priscilla Lady Padaga ${ }^{1}$, Lamria Raya Fitriyani ${ }^{* *}$ \\ ${ }^{1,2}$ Program Studi Ilmu Komunikasi, Institut Komunikasi dan Bisnis LSPR, \\ Intiland Tower, Jl. Jend. Sudirman, Karet Tengsin, Jakarta \\ Email: 1ladypadaga@yahoo.com, 2lamria.rf@1spr.edu
}

\begin{abstract}
ABSTRAK
Penelitian ini bertujuan untuk mengetahui bagaimana gaya komunikasi Christofer Tapiheru dalam membentuk personal branding. Banyaknya jumlah pengikutnya yang bertambah setiap harinya di media sosial, tentunya ada sesuatu yang menarik dari gaya komunikasi yang ditampilkan dan personal branding yang terbentuk dari gaya komunikasi tersebut. Metode penelitian yang digunakan adalah metode penelitian kualitatif, dengan melakukan wawancara. Berdasarkan hasil penelitian, Christofer Tapiheru tidak seperti pendeta pada umumnya, yaitu tidak menempuh pendidikan resmi di sekolah teologi, dan gaya bahasa yang ditampilkan adalah gaya bahasa yang mendarat dan santai. Christofer Tapiheru hanya ingin menampilkan dirinya apa adanya dan hal itu benar-benar dapat dilihat oleh khalayaknya. Gaya komunikasi Christofer Tapiheru adalah gaya komunikasi Equalitarian Style, dimana Christofer melihat khalayak nya secara setara dengannya, mengingat bahwa Christofer menganggap khalayaknya sebagai keluarga, dan bukan cuma sekedar penggemar. Gaya komunikasi tersebut membentuk personal branding sebagai sosok pendeta yang tidak biasa, apa adanya dan sosok yang mudah didekati oleh khalayak.
\end{abstract}

Kata kunci: Personal Branding, Gaya Komunikasi, Christofer Tapiheru.

\begin{abstract}
The purpose of this research is to find out the communication style of Ps. Christofer Tapiheru to form his personal branding, there must be something that interests the audience regarding the communication style he uses and the personal branding that is formed by that communication style. This research is focused on the personal branding by the communication style that is displayed by Christofer Tapiheru. The research method used is qualitative research methods, by conducting interviews. Based on the result of the research, Christofer Tapiheru is not like the usual pastor, he doesn't go to a theology school, and the language style that he presents is more down-to-earth and laid back. Christofer Tapiheru just wants to show how he really is and that really can be seen by his audiences. Christofer Tapiheru's communication style is the equalitarian communication style, whereas Christofer Tapiheru sees his audience as equal to him, seeing how he considered them family and not just his fans. That communication style has formed Christofer Tapiheru's personal branding as a non typical pastor, being just the way he is and approachable by his audiences.
\end{abstract}

Keywords: Personal branding, Communication style, Christofer Tapiheru.

\section{PENDAHULUAN}

Seorang tokoh masyarakat tentu akan membangun personal branding dalam skala yang lebih besar, sehingga pesan tersebut dapat menjangkau jumlah khalayak yang banyak dan khalayak bisa melihat keunikan tokoh masyarakat atau figur tersebut diantara figur yang lain. Selain itu, membangun personal branding juga tidak sampai di tampilan luar masing-masing individu, tetapi dari output dari individu itu sendiri. Personal brand yang ditampilkan haruslah seotentik mungkin, karena saat personal brand yang dijanjikan sejalan dengan personal brand yang dilihat, maka hal itu berpengaruh dalam membangun kredibilitas seseorang.

Bagi seorang public figure, pembangunan personal branding pun dapat dilakukan dengan banyak hal, baik dengan menjangkau khalayak secara langsung dengan mengadakan even, pertemuan dengan stakeholder secara langsung, dan sebagainya. Selain mendekati khalayak secara langsung, seorang public figure dapat menggunakan personal branding tools pendukung lainnya yang tersedia (Montoya and Vandehey, 2008). Pembangunan personal branding oleh public figure tidak hanya terbatas pada pada public figure di bidang hiburan komersil, personal branding juga sesuatu yang penting bagi tokoh agama. Sebagai tokoh agama, publik menaruh kepercayaan kepada tokoh tersebut sebagai teladan bagi masyarakat. Salah satu tokoh masyarakat yang dekat dengan khalayak muda yaitu Ps. Christoper Tapiheru., sebelum dikenal sebagai seorang pendeta, Christofer bekerja sebagai seorang desainer grafis untuk sebuah perusahaan swasta. Christofer Tapiheru sekarang melayani sebagai seorang pendeta muda di 
New Wine International Church, dan terkadang juga melayani diluar gereja bersama dengan kedua adiknya, Gamaliel dan Audrey Tapiheru dalam GAC Ministry.

Sebagai pendeta muda, Ps. Christofer Tapiheru menjangkau khalayak nya melalui berbagai platform, seperti media sosial, melalui kanal YouTube, Podcast di revivo, dan akun Instagram pribadinya. Gaya komunikasi Christofer Tapiheru terlihat sebagai gaya komunikasi yang santai, apa adanya dan terlihat seperti ingin menjangkau anak-anak muda pada saat berkhotbah atau berbicara di khalayak publik. Dugaan tersebut juga dilihat dari konten Instagram yang diunggahnya dan bisa dilihat juga dari video YouTube, dan caranya saat berkhotbah. Bahasa yang digunakan tidak menggunakan bahasa yang kaku, kecuali saat mengutip Alkitab itu sendiri. Jawaban. com menyebut Christofer Tapiheru sebagai "pastor gaul" (Marpaung, 2017). Melihat dari julukan tersebut, penulis tertarik dengan gaya komunikasi yang ditampilkan oleh Ps. Christofer Tapiheru sebagai seorang tokoh agama dan bagaimana hal tersebut dapat membentuk personal branding Ps. Christofer Tapiheru.

Berbagai personal branding tools, salah satu yang digunakan Christofer Tapiheru adalah Instagram, konten Instagram Ps. Christofer Tapiheru meliputi kata-kata motivasi bagi anak muda yang mendorong anak muda untuk rajin beribadah dan berbagai pesanpesan injil yang diselipkan dengan situasi kehidupan sehari-hari. Tidak hanya kata-kata motivasi, Ps. Christofer juga menunjukkan bahwa dirinya tidak seperti pendeta pada umumnya dengan mempopulerkan tagar \#NotYourTypicalPastor. Melalui tagar tersebut, Ps. Christofer mengunggah ketertarikan dan kegiatan yang dia lakukan sehari-hari. Dengan jumlah pengikut sebanyak 155k pengikut (Per Oktober 2020), akun Instagram@christofertapiheru menjadi salah satu akun Instagram populer di antara public figure di bidang serupa dengan Ps. Christofer. Seperti yang dikatakan sebelumnya oleh peneliti, tidak hanya melalui media sosial Instagram, Christofer juga menjangkau audience nya dengan menggunakan YouTube. Per Oktober 2020, kanal YouTube Christofer di subscribe oleh sekitar 11, 2k. Christofer Tapiheru ditarik oleh Lembaga Alkitab Indonesia untuk menjadi brand ambassador dari campaign yang mengajak anak muda untuk kembali menggunakan Alkitab berbasis cetak untuk mendukung ibadahnya. Campaign tersebut dinamakan G49 (Gerakan baca Alkitab 4-9 pasal) dan dipopulerkan dengan tagar \#MakeAlkitabCetakGreatAgain,\#GueMudaGueBacaAlkita, dsb. Campaign G49 meliputi rencana pembacaan Alkitab yang disusun bersama Christofer Tapiheru yang dibagikan melalui Instagram untuk mengajak khalayak untuk ikut ambil bagian dalam rencana bacaan tersebut dan membagikannya di akun Instagram masing-masing.

Mengenai penampilan, Christofer punya alasan tersendiri untuk menampilkan dirinya sedemikian rupa. Baginya, ia hanya ingin menjadi diri sendiri. Bagi Christofer, orang-orang (khususnya orang yang ia layani di gereja) bukan mencari orang yang sempurna, tetapi mereka mencari orang yang nyata/apa adanya. Jika kita melakukan itu, mereka pasti akan mendengarkan kita. Perkenalan Christofer sendiri dengan media sosial diawali dari keinginannya untuk membuat kutipan-kutipan yang suka dilakukannya. Daripada hanya jadi konsumsi pribadi, ia berpikir untuk membagikannya kepada orang lain (Marpaung, 2017)

Berdasarkan dengan latar belakang diatas, maka rumusan masalah pada penelitian ini adalah bagaimanakah gaya komunikasi Ps. Christoper Tapiheru dalam membentuk personal branding? Tujuan penelitian ini untuk menganalisis gaya komunikasi Ps. Christoper Tapiheru dalam membentuk personal branding.

Penelitian terdahulu mengenai personal branding sudah dilakukan. Salah satu penelitian terdahulu yang digunakan, yaitu berjudul Strategi Menciptakan, Mempertahankan dan Menjual Personal Branding, Jelang Pemilu 2014. Priyono mengemukakan bahwa dalam konteks pemilu 2014, ada partai yang dinilai cukup sukses dan ada juga yang gagal dalam membangun brand. Selain partai, Priyono juga menjadikan beberapa tokoh politik sebagai sebagai contoh baik dalam hal keberhasilan atau kegagalan membagun personal branding, diantaranya adalah, K.H. Abdullah Gymnastiar (AA Gym) dan Puspawardoyo (pemilik Ayam Bakar Wong Solo) sebagai pihak yang gagal dalam personal branding. Menurut Priyono, tokohtokoh yang berhasil dalam personal branding adalah Ir. Soekarno, Abdurrahman Wahid (Gus Dur), Joko Widodo, dan seterusnya.

Priyono memberi paparan bahwa personal branding dapat diklasifikasikan menjadi tiga indikator yaitu, kelompok-kelompok sosial, kredibilitas kandidat, dan kepribadian kandidat. Dari indikator-indikator tersebut dapat diuraikan menjadi beberapa sub indikator. Unit analisis untuk kelompok sosial diukur melalui latar belakang pekerjaan. Sub Indikator untuk kredibilitas kandidat adalah keahlian/otoritas, karakter/watak, dinamisme dan intention, yang dilihat dari kecerdasan, wibawa, andal, objektivitas, motivasi, kemampuan persuasi, semangat, keberanian dan ketegasan. 
Sedangkan unit analisis untuk kepribadian kandidat dilihat dari kesopanan, sikap ramah, sikap menarik, kepercayaan diri, dan kemampuan untuk membangun hubungan (bersahabat). Jurnal ini dijadikan referensi oleh peneliti melihat kesamaannya meneliti personal branding tokoh-tokoh publik, penelitian ini terfokus pada 8 konsep personal branding Montoya. Metode penelitian yang digunakan adalah metode penelitian kualitatif (Priyono, 2014).

Penelitian selanjutnya dengan judul 'Analisis Gaya Komunikasi Ahmad Faiz Zainuddin' Dalam penelitian ini, Pratiwi memfokuskan penelitiannya kepada enam gaya komunikasi, dan penelitian digunakan dengan metode kualitatif pendekatan deskriptif. Objek penelitian yang digunakan adalah dua video dari Ahmad Faiz Zainuddin dimana Pratiwi mengamati komunikasi verbal dan non verbal yang merujuk pada gaya komunikasi. Ahmad Faiz Zainuddin adalah founder Spiritual Emotional Freedom Technique (SEFT) yang merupakan terapi yang menggabungkan llmu akupuntur dan psikologi yang disempurnakan dengan sentuhan spiritual yang bersifat universal. Kecenderungan gaya komunikasi Ahmad Faiz Zainuddin pada video pertama merujuk ke gaya komunikasi the controlling style dan pada video kedua menggunakan gaya komunikasi the equalitarian style. Perbedaan gaya komunikasi yang digunakan oleh Ahmad Faiz Zainuddin pada video yang diteliti dikarenakan perbedaan komunikan yang dihadapi sehingga ia menyesuaikan dengan kondisi yang ada. Sesuai teori yang digunakan yaitu teori dramaturgi oleh Ervin Goffman dimana komunikator dianalogikan sebagai aktor yang memainkan peran sesuai kondisi yang dibutuhkan dan dalam situasi tertentu. Pratiwi menyimpulkan dari hasil penelitiannya bahwa Ahmad Faiz Zainuddin menggunakan gaya komunikasi the controlling style dan the equalitarian style dalam berinteraksi dengan komunikannya dan sebagai komunikator Ahmad Faiz Zainuddin mampu memainkan perannya sesuai kondisi yang dibutuhkan sehingga pesan yang ingin disampaikan tersalurkan dengan baik (Pratiwi, 2017).

Artikel jurnal ini menjadi referensi bagi peneliti karena melihat kesamaan topik yang dibahas, yaitu gaya komunikasi. Metode penelitian yang digunakan pun sesuai dengan yang digunakan peneliti yaitu metode penelitian kualitatif.

\section{KAJIAN PUSTAKA}

\subsection{Gaya Komunikasi}

Raynes (Liliweri, 2011) memandang gaya komunikasi sebagai campuran unsur-unsur komunikasi lisan dan ilustratif. Pesan-pesan verbal individu yang digunakan individu untuk berkomunikasi diungkapkan dalam kata-kata tertentu yang mencirikan gaya komunikasi. Gaya komunikasi adalah seperangkat perilaku antar pribadi yang terspesialisasi digunakan dalam situasi tertentu. Masing-masing gaya komunikasi terdiri dari sekumpulan perilaku komunikasi yang dipakai untuk mendapatkan respons atau tanggapan tertentu dalam situasi tertentu pula (AW, 2011).

Norton menyampaikan gaya komunikasi dapat didefinisikan sebagai cara seseorang dapat berinteraksi dengan cara verbal dan para verbal, untuk memberi tanda bagaimana arti yang sebenarnya harus dipahami atau dimengerti (Cutlip et al., 2006).

Berdasarkan definisi-definisi diatas, penulis menyimpulkan bahwa gaya komunikasi adalah sekumpulan perilaku yang dapat mempengaruhi respon penerima pesan terhadap pesan yang disampaikan komunikator.

(Tubbs \& Moss, 2009) mengelompokkan gaya komunikasi menjadi enam kelompok, sebagai berikut:

1. Controlling Style

Gaya komunikasi controlling ditandai dengan adanya satu kehendak atau maksud untuk membatasi, memaksa dan mengatur perilaku, pikiran dan tanggapan orang lain. Orang-orang yang menggunakan gaya komunikasi ini dikenal sebagai komunikator satu arah (one way communicators). Para komunikator satu arah tersebut tidak memperdulikan pandangan negatif orang lain, tetapi justru berusaha menggunakan kewenangan dan kekuasaan untuk memaksa orang lain mematuhi pandangan-pandangannya.

Pesan-pesan yang disampaikan dengan gaya komunikasi controlling bertujuan untuk mempersuasi orang lain supaya bekerja dan bertindak efektif dan pada umumnya berbentuk kritik.

2. Equalitarian Style

Dalam gaya komunikasi ini, komunikasi dilakukan secara terbuka. Suasana demikian memungkinkan komunikator untuk mencapai kesepakatan dan pengertian bersama. Aspek penting dalam gaya komunikasi ini adalah kesamaan.

Gaya komunikasi equalitarian menekankan pengertian bersama sehingga terjadi kesepakatan dan memiliki tingkat kepedulian yang tinggi serta kemampuan dalam membina hubungan yang baik.

3. Structuring Style

Structuring style memanfaatkan pesan-pesan verbal secara tertulis atau lisan untuk memantapkan perintah yang harus dilaksanakan. Salah satu hal yang paling menonjol dalam gaya komunikasi ini adalah keobjektifannya. Pengirim pesan lebih memberi perhatian kepada keinginan untuk 
mempengaruhi orang lain dengan jalan berbagi informasi.

4. Dynamic Style

Gaya komunikasi ini memiliki kecenderungan untuk menjadi agresif, karena pengirim pesan melihat lingkungannya sebagai lingkungan yang action-oriented. Gaya komunikasi yang agresif tersebut bertujuan untuk menstimulasi pekerja untuk bekerja dengan lebih cepat, sehingga gaya komunikasi ini cukup efektif untuk digunakan dalam mengatasi masalah kritis.

5. Relinguishing Style

Gaya komunikasi ini mencerminkan kesediaan untuk menerima saran, pendapat atau gagasan dari pihak lain, dibandingkan dengan keinginan untuk memberi perintah meskipun pengirim pesan berhak untuk memberi perintah dan mengendalikan orang lain. Komunikator dengan gaya komunikasi ini bersifat suportif terhadap pandangan orang lain. Gaya komunikasi ini efektif saat komunikator sedang bekerjasama dengan orangorang berpengetahuan.

6. Withdrawal Style

Dalam gaya komunikasi ini, komunikator bersifat independen dan justru menghindari tindak komunikasi. Gaya komunikasi ini dapat melemahkan tindak komunikasi karena komunikator tidak ingin berkomunikasi dengan orang lain. Gaya komunikasi ini bersifat mengalihkan persoalan yang sedang terjadi.

\subsection{Personal Branding}

"Personal Brand adalah makna dan asosiasi tentang diri kita yang sampai kepada audience kita untuk membangun reputasi dan trust." '(Maulana, 2015). "Personal branding merupakan brand yang dibangun diatas manusia, bukan barang atau produk yang mempunyai identitas yang pasti. Ada dua hal yang harus dimiliki oleh seseorang yang ingin membentuk brand personal, yaitu entitas yang mudah dikenali dan menjanjikan nilai tertentu" (Nicolino, 2004) "Kemampuan untuk menggunakan atribut yang menunjukan kemampuan anda untuk mengelola ekspektasi yang akan diterima dari pertemuan dengan anda" (Mobray, 2009).

"Personal branding adalah mengendalikan bagaimana pandangan orang lain terhadap anda sebelum berhubungan langsung dengan anda." (Montoya and Vandehey, 2008). Definisi-definisi diatas, dapat disimpulkan bahwa proses personal branding adalah bagaimana seseorang dapat membentuk persepsi orang terhadap dirinya, bahkan dari hal yang terlihat saja. Personal Branding pada seseorang adalah segala hal yang membedakan orang tersebut terhadap orang lain, hal itu dapat meliputi dari penampilan, cara berpakaian, cara berkomunikasi, dan sebagainya.

O'brien juga menyampaikan, Kegiatan atau aktifitas dalam membangun sebuah personal branding, adalah untuk mengkomunikasikan dan memastikan bahwa orang lain akan menerima dan mempercayai nilai dan identias yang ada pada individu tersebut (dalam Imawati, Solihah dan Shihab, 2016).

Akan tetapi Haroen (2014) menyampaikan bahwa persepsi yang ada dalam benak orang lain, yaitu personal brand tidak boleh merendahkan bersifat menipu karena secara langsung personal brand yang kuat harus dapat mewakili bagaimana karakter diri individu tersebut (dalam Salam, 2020).

Menurut (Montoya and Vandehey, 2008) 3 hal berikut perlu diketahui untuk menghindari kerugian dalam membentuk branding.

\section{- Clarity}

Tetapkan satu pesan yang mudah dan jelas. Jangan merumitkan calon klien anda dengan berbagai alasan untuk memilih anda. Saat seseorang melihat brand anda, orang tersebut harus bisa langsung mengetahui siapa anda (nama, apa yang anda wakilkan), dan apa yang anda lakukan (layanan yang anda sediakan secara spesifik dan untuk siapa anda menyediakan pelayanan anda).

- Specialization

Kunci kedua ini dapat disimpulkan dengan akal, anda harus memiliki perbedaan dari kompetitor anda agar menonjol. Specialization berarti anda memantapkan satu "posisi" yang sangat tetap di tengah marketplace sehingga membedakan anda dengan kompetitor.

- Consistency

Seseorang mempunyai banyak hal yang dapat membagi perhatiannya. Umumnya, seseorang baru akan memperhatikan dan menghargai brand anda setelah dipaparkan beberapa kali. Hal itu berarti sangat penting bagi anda untuk menampilkan personal brand anda berulang-ulang dalam suatu periode waktu tertentu. Tetap biarkan pesan dasar yang sama.

Personal branding dapat dibagi menjadi tiga elemen utama, yakni: You, dengan kata lain, orang itu sendiri. Personal branding dikembangkan melalui sebuah metode komunikasi yang dipoles dan disusun dengan baik. Dirancang untuk menyampaikan dua informasi vital kepada target market, yaitu: 
- Siapakah anda sebagai suatu pribadi

- Apa spesialisasi anda

Personal brand adalah sebuah gambaran mengenai apa yang masyarakat pikirkan tentang seseorang. Personal brand mewakili nilai-nilai, kepribadian, keahlian dan kualitas yang membuat seseorang berbeda dengan kompetitornya. Karena itulah, menjadi otentik dalam membuat brand anda itu penting.

Promise. Personal brand adalah sebuah janji, personal brand dapat menjadi gambaran ekspektasi calon klien anda tentang anda.

Relationship. Sebuah personal branding yang baik akan mampu menciptakan suatu relasi yang baik dengan klien, semakin banyak atribut- atribut yang dapat diterima dengan klien dan semakin tingginya tingkat kekuasaan seseorang,menunjukkan semakin baiknya tingkat relasi yang ada pada personal branding tersebut (Montoya and Vandehey, 2008).

Peneliti memfokuskan penelitian kepada tiga elemen personal branding yang disebutkan diatas mengingat bahwa ketiga elemen tersebut tidak hanya terfokus pada pembentukan personal brand, tetapi menekankan hubungan antara subjek penelitian dan khalayaknya.

\section{METODE PENELITIAN}

Penelitian ini dilakukan dengan metodologi penelitian kualitatif. Penelitian kualitatif merupakan bidang penyelidikan yang berdiri sendiri. Penelitian ini menyinggung aneka disiplin ilmu, bidang, dan tema (Denzin \& Lincoln, 2009)

Dalam penelitian ini, narasumber yang dipilih peneliti adalah key person yang bisa memberikan pemahaman tentang informasi yang dibutuhkan dalam penelitian. Narasumber pada penelitian ini adalah Christofer Tapiheru (sebagai subjek yang diteliti), Lovelia Chandradinata (istri Christofer yang mendampinginya dalam setiap kegiatan), Samuel Simatupang (salah satu dari sekian banyak followers Christofer) dan Jonathan Theofilus (sebagai seseorang yang secara berkala bertemu dengan Ps. Christofer Tapiheru).

\section{ANALISIS DAN PEMBAHASAN}

Penelitian ini bertujuan untuk mengetahui gaya berkomunikasi Ps. Christofer Tapiheru dan bagaimana gaya komunikasi tersebut membentuk personal brandingnya, dan setelah melakukan pengumpulan data, peneliti mendapatkan hasil penelitian yang menunjukkan bahwa Christofer Tapiheru sudah memiliki personal branding yang kuat yang didukung dengan gaya komunikasi yang khas.

Dilihat dari ketiga elemen personal branding, yang pertama adalah elemen you, elemen ini berbicara tentang siapa subjek sebagai pribadi, nlai- nilai apa yang melekat pada subjek tersebut dan spesialisasi dari subjek tersebut. Christofer Tapiheru memiliki kekuatan dalam elemen You, Christofer benar-benar memahami apa yang ia ingin tampilkan melalui dirinya, sehingga tidak mudah terpengaruh pihak luar atau tanggapan negatif sekalipun. Dari sisi penampilan, Christofer selalu berpenampilan apa adanya, dengan pakaian yang sederhana dan gaya bahasa yang mudah ditangkap oleh orang-orang. Penampilannya pun tidak tergantung dengan preferensi orang, ia hanya menampilkan dirinya apa adanya, jika banyak lapisan masyarakat yang terbiasa dengan melihat sosok pendeta dengan tampilan tertentu, Christofer tidak merasa perlu untuk mengikuti standar itu, karena yang terpenting untuk Christofer tunjukkan adalah menjadi dirinya sendiri dan menampilkan dirinya apa adanya. Sehingga khalayaknya bisa menjangkaunya dengan mudah. Christofer benar-benar bertahan pada personal brandingnya sebagai seorang "tukang surat" sehingga setiap aktivitas yang ia lakukan bertujuan utama untuk menyampaikan pesan khusus untuk khalayaknya, pesan yang bukan ia ciptakan sendiri, sehingga pesan yang ia terima untuk ia bagikan, tidak dimodifikasi untuk disesuaikan dengan preferensi diri sendiri maupun preferensi khalayak. Hal itu ia dapat karena pada prinsipnya, Christofer hanya ingin menyampaikan pesan yang dia terima. Christofer memiliki anggapan bahwa firman Tuhan adalah surat cinta, dan ia ingin membagikannya dan membawanya kemanapun ia pergi, bahkan sebelum ia menekuni profesinya saat ini sebagai seorang pendeta. Pada saat ia masih menjadi karyawan di sebuah perusahaan, ia sudah melakukan apa yang ia rasa menjadi tugasnya yang adalah sebagai pengantar surat dengan membuka persekutuan di tempat kerjanya. Apapun profesi yang ia tekuni, baik sebagai karyawan di kantor, hingga menjadi pendeta dan penginjil keliling, Christofer sudah mengetahui tugas utama yang harus ia lakukan.

Christofer mengemukakan bahwa pada dasarnya tujuannya adalah untuk memperkenalkan, dan hal itu diperlihatkan dari pendekatan yang ia gunakan kepada khalayaknya. Melihat pada latar belakang Christofer yang tidak bersekolah Alkitab, hal itu membuat pendekatannya menjadi awam, sehingga bahasa yang digunakan pun adalah bahasa yang ia anggap sebagai 
bahasa "jalanan", dan gaya bicaranya seringkali seperti gaya bercakap-cakap sehari-hari, sehingga ia menampilkan dirinya sebagai seseorang yang mudah diajak bicara oleh khalayak, bukan sebagai pengkhotbah.

Gaya komunikasi yang Christofer tampilkan dapat memberikan rasa kedekatan kepada khalayaknya, karena Christofer pun tidak menganggap bahwa ia memiliki posisi yang lebih tinggi dibanding khalayaknya. Justru ia ingin menjadi seseorang yang dapat membuat Yesus atau hal-hal kerohanian menjadi sesuatu yang accessible. Saat ada orang yang mendekatinya untuk saling bertukar pikiran, Christofer akan menunjukan sikap yang terbuka dan menerima, walaupun akan sulit untuk mempengaruhi brand yang sudah melekat pada Christofer. Gaya komunikasi yang ia tampilkan seringkali menunjukan gaya komunikasi sebagai orang awam, karena ia ingin pesan yang ia sampaikan mudah dimengerti banyak orang dari berbagai lapisan masyarakat.

Dalam berkhotbah, Christofer mempraktekan ilmu retorika, khotbahnya disampaikan untuk dapat mempengaruhi khalayak agar dapat menghidupi pesan dan nilai-nilai yang ia ingin sampaikan kepada khalayak. Pengaruh yang ingin ia berikan kepada khalayak, tidak berhenti pada khotbah saja, tetapi disesuaikan dengan caranya berkomunikasi dalam kehidupan sehari-hari. Interaksi secara langsung pun khalayak merasa bahwa gaya komunikasi yang ditampilkan Christofer tetap sama. Baik dalam komunikasi publik saat berkhotbah atau dalam pembicaraan pribadi. Christofer tetap menunjukan gaya komunikasi yang memberi kesan kedekatan, dan sangat terbuka untuk pertanyaan. Dalam khotbahnya pun ia menyampaikan Gaya komunikasi Christofer yang tidak biasa untuk seorang pendeta membuat banyak pihak menjadi salah sangka. Ada pihak-pihak tertentu yang menganggap bahwa gaya komunikasi Christofer tidak sesuai atau tidak pantas sebagai seorang pendeta, karena ada yang menganggap bahwa gaya komunikasi Christofer dapat terbilang kasar. Banyak yang menjadi salah sangka terhadap hal itu, dengan pandangannya yang hanya ingin membagikan pesan, Christofer tidak memodifikasi pesan yang ia sampaikan sesuai dengan preferensi orang, tetapi pesan yang ia sampaikan adalah teguran-teguran yang ia dapatkan sendiri. Banyak pihak yang tidak melihat itu, sehingga ada pihak-pihak khalayak yang beranggapan bahwa Christofer menegur mereka dengan keras, padahal tidak ada niatan seperti itu dari Christofer. khotbahnya dengan bahasa sehari-hari sehingga mudah dimengerti bagi orang-orang yang mungkin hanya melihat cuplikannya di media sosial.
Elemen you berbicara tentang siapa subjek sebagai pribadi, dan setelah mengumpulkan data terkait, peneliti melihat bahwa Christofer sudah benar-benar tahu siapa dirinya sebagai seorang pribadi, baik untuk ditampilkan di publik maupun dalam interaksi tingkat personal.

Elemen promise berbicara tentang apa yang bisa diberikan subjek kepada khalayak dan apa yang bisa diekspektasikan oleh khalayak kepada subjek, dilihat dari elemen promise, Christofer tidak memberikan suatu janji yang terlalu muluk untuk khalayaknya, Christofer cukup menjanjikan bahwa ia hanya menjadi dirinya sendiri, sehingga Christofer tidak ingin mengikuti stereotip tokoh agama pada umumnya. Nilai yang ingin Christofer berikan kepada khalayak adalah mengenai keutamaan hal yang rohani dalam kehidupan sehari-hari, sehingga hal rohani tersebut bisa dijalani secara alami, dan hal tersebut dapat dilihat oleh khalayaknya, baik yang mengenal Christofer dari media sosial, yang mengenalnya sebagai pengkhotbah, atau yang mengenalnya secara personal, dapat dilihat bahwa nilai yang Christofer ingin berikan sudah tersampaikan kepada khalayak yang dapat melihat betapa pentingnya kerohanian dalam hidup melalui pesan-pesan yang Christofer sampaikan.

Elemen promise juga berbicara tentang ekspektasi, ekspektasi seringkali menjadi hal yang berlawanan dengan Christofer. Dengan profesinya sebagai seorang pendeta, ada ekspektasi tertentu dari masyarakat untuk Christofer ikuti, tetapi Christofer menegaskan dalam banyak kesempatan bahwa Christofer tidak ingin mengikuti ekspektasi yang sudah ada karena tidak sesuai dengan dirinya, ia meyakini bahwa semua orang memiliki ciri khas masing-masing, sehingga yang Christofer janjikan adalah untuk menjadi dirinya sendiri sehingga dapat menampilkan ciri khas tersebut dan menunjukan otentisitasnya. Otentisitasnya itulah yang dapat menjadi hal yang paling bisa diekspektasi khalayak dari Christofer.

Sikap dan penampilan Christofer yang menampilkan dirinya apa adanya, memberikan suatu kesan otentik yang melekat pada Christofer. Otentisitas yang bisa diekspektasi dari Christofer Tapiheru berkaitan dengan pesan yang ingin ia sampaikan kepada khalayak. Christofer Tapiheru ingin memberikan nilai atau pemahaman kepada khalayaknya bahwa hal-hal kerohanian dalam kehidupan sehari-hari menjadi suatu keutamaan. Christofer menunjukan bahwa ibadah bagi manusia adalah hal yang alami, dan dengan menampilkan dirinya seotentik mungkin, dengan cara berkhotbahnya, dan bagaimana ia berinteraksi dengan khalayak, Christofer menunjukan 
bahwa ibadah yang Christofer jalani dijalani secara alami, bukan hanya karena untuk ditampilkan dihadapan umum karena ia adalah seorang yang berprofesi sebagai pendeta/pengkhotbah.

Sebuah "janji" dari personal branding seseoang tentunya harus ditepati, begitu pula dalam hal personal branding, dan hal ini sudah dilakukan Christofer dengan baik. "Janji" dari personal branding Christofer adalah untuk menjadi dirinya sendiri, sehingga untuk menepati janji tersebut menjadi hal yang terjadi secara alami. Christofer juga dapat mempertahankan personal brandingnya dengan konsisten, baik dilihat dari berjalannya waktu, maupun dari tingkat kedekatan khalayak yang melihat dan berinteraksi dengan Christofer. Baik khalayak yang mengenal Christofer melalui media sosial, yang melihat ia berkhotbah, atau yang mengenal Christofer secara personal, semua mengkonfirmasi bahwa pesan dan personal branding yang ditampilkan sudah disampaikan dan ditampilkan secara konsisten.

Elemen personal branding terakhir adalah relationship, elemen relationship berbicara tentang bagaimana subjek membangun hubungan dengan stakeholders, bukan hanya dengan pihak-pihak yang bersifat menguntungkan untuk subjek saja, tetapi dengan para kompetitor juga. Dalam elemen ini, sangat mudah untuk menggambarkan hubungan Christofer dengan khalayaknya sebagai teman, bahkan keluarga. Karena anggapan tersebut, Christofer membuka ruang untuk khalayaknya untuk membangun hubungan yang lebih dekat dengannya, dan ruang itu terbuka untuk siapa saja, bukan cuma untuk mereka yang ingin mengenal Christofer atau bertanya-tanya mengenai kekristenan, bahkan untuk yang ingin memberi kritik atau tanggapan negatif secara langsung pun Christofer juga membuka ruang untuk bertemu. Dengan sikap Christofer yang terbuka tersebut, benar-benar terlihat bahwa Christofer juga menghargai hubungannya dengan khalayak, baik untuk memberikan saran atau dukungan, atau bahkan untuk memberikan sanggahan, Christofer tetap menerimanya.

Dengan rekan-rekan yang seprofesi dengannya pun, Christofer tidak menganggap mereka sebagai kompetitor, bahkan Christofer menganggap mereka sebagai partner kerja. Karena pada dasarnya tujuan Christofer adalah untuk memperkenalkan Tuhan kepada mereka yang belum mengenal Tuhan, Christofer tidak merasa berambisi untuk menjadi yang paling terkenal di bidangnya, semakin banyak orang yang seprofesi dengannya, semakin bagus, karena berarti semakin banyak orang yang menyampaikan pesan yang sama dengannya sehingga dapat menjangkau lebih banyak orang.

Christofer Tapiheru sudah tahu brand apa yang ia ingin tampilkan bahwa sebelum ia menjadi seorang public figure, ia ingin terlihat sebagai orang yang otentik dan apa adanya, tetapi jika dikaitkan dengan profesinya sebagai pendeta, hal itu menuai berbagai macam reaksi dari berbagai pihak. Menurut pengalaman Christofer, banyak pihak yang mempunyai ekspektasi tertentu terhadap pendeta, pendeta diekspektasi untuk mengemban pendidikan di sekolah Teologi, pendeta harus memiliki tampilan clean image, dsb. Hal-hal tersebut tidak sepenuhnya sesuai dengan Christofer, ada pihak- pihak khalayak Christofer yang menganggap gaya bahasanya termasuk "kasar" untuk seorang pendeta, ia mendapatkan pengetahuan Alkitabnya melalui grup pembelajaran Alkitab non-formal, penampilannya tidak seperti pendeta pada umumnya yang berkhotbah memakai jas, atau menampilkan suatu wibawa tertentu. Karena Christofer sudah mengerti benar apa yang ia ingin tampilkan, yaitu otentitasnya, Christofer jadi tidak mudah terpengaruh dengan kritikan, tetapi hal itu tidak menutup Christofer untuk menerima saran.

Dapat dilihat dari konten media sosialnya bahwa halhal yang ia sampaikan seringkali tertuju pada aspekaspek hubungan pribadi manusia dengan Tuhan, karena pada dasarnya, pesan-pesan itu adalah rhema pribadi untuk Christofer, yang akhirnya ia bagikan melalui media sosial dan tentunya juga menjadi bahan khotbah. Hal itu ia lakukan bukan dengan maksud merasa lebih tinggi dari khalayaknya, tetapi hal itu ia lakukan mengingat tujuannya sebagai seorang pendeta yaitu menjadi "tukang surat" atau penyampai pesan. Christofer tidak hanya menyampaikan pesan yang ia ingin perkenalkan melalui media sosial atau khotbah, tetapi dari hal-hal yang ia dukung juga. Produkproduk yang meng-endorse-nya kebanyakan adalah merek berbasis Kristen yang awalnya ia sudah pakai, karena Christofer merasa dengan keberadaannya sekarang di mata publik dapat bermanfaat juga untuk rekan- rekan pengusaha yang mempromosikan nilainilai yang sama dengan Christofer, contoh yang dapat dilihat adalah lini busana "Messenjah". Christofer juga menjadi brand ambassador pada satu kampanye dari Lembaga Alkitab Indonesia dan menjadi kontributor dari produk terbaru LAI yaitu, Alkitab Jurnal. Jika dilihat sekilas, Christofer terlihat seperti public figure pada umumnya yang ditarik menjadi brand ambassador, tetapi peran Christofer tidak hanya sampai disitu, Christofer dijangkau langsung oleh Lembaga Alkitab Indonesia dalam proses penggarapan Alkitab 
Jurnal sehingga menjadi produk yang ada di pasaran saat ini. Alkitab Jurnal dirancang oleh Christofer dan tim dari LAI untuk menjawab suatu kebutuhan yang Christofer rasa belum terjawab, yaitu kedekatan tersendiri antara pembaca Alkitab dengan Alkitabnya, menurut Christofer, saat seseorang merasa mempunyai sentuhan pribadi dengan Alkitabnya, orang tersebut akan merasa dekat dengan firman, dan hal itu selaras juga dengan pesan yang ingin Christofer sampaikan mengenai keutamaan kehidupan rohani yang dapat dibangun dengan membaca Alkitab secara rutin.

Dilihat dari pembahasan diatas, peneliti melihat gaya komunikasi Christofer Tapiheru yang termasuk gaya komunikasi equalitarian style membentuk personal brandingnya sebagai pastor yang accessible, dan mendukung personal branding Christofer yang sudah terbangun sebagai seorang pastor yang bergaya apa adanya.

Setelah mengumpulkan data-data penelitian, peneliti mendapatkan beberapa temuan baru berkaitan dengan gaya komunikasi Ps. Christofer Tapiheru dalam membentuk personal branding.

- Gaya komunikasi dalam membentuk personal branding

Gaya komunikasi yang ditampilkan Christofer Tapiheru adalah gaya komunikasi equalitarian style, yaitu dimana Christofer melihat khalayaknya secara setara dengannya, mengingat bahwa Christofer menganggap khalayaknya sebagai keluarga, dan bukan cuma sekedar penggemar. Gaya komunikasi tersebut membentuk personal branding sebagai sosok pendeta yang tidak biasa, apa adanya dan sosok yang mudah didekati oleh khalayak, dan gaya komunikasi tersebut membentuk personal branding Christofer Tapiheru sebagai sosok yang accessible, gaya komunikasi tersebut membuat khalayak menjadi dekat dengannya sehingga dapat membangun hubungan juga dengan Christofer.

- Personal Branding Christofer Tapiheru

Melihat eksistensi Christofer dihadapan publik, tentunya hal itu terlihat seperti suatu brand yang dibangun, tetapi bukan begitu nyatanya. Tidak ada usaha khusus untuk menonjolkan konsep dirinya kepada khalayak, dan tidak ada standar khusus mengenai konten atau pesan yang ingin ditampilkan, semua aktivitas Christofer hanya sesederhana menjadi dirinya sendiri, sesuai dengan pesan yang ingin Christofer sampaikan yaitu mengenai doktrin teologi Imago Dei. Personal branding yang ditampilkan sama pada saat berkhotbah, dalam konten-konten media sosial dan saat menjalin komunikasi dengan khalayak.

- Hubungan dengan khalayak

Dari personal branding yang ditampilkan Christofer Tapiheru, khalayak sudah mendapatkan pesan yang sama dari berbagai aspek. Baik dari cara berpakaian yang ditampilkan Christofer, caranya berkhotbah, dan konten media sosial yang Christofer unggah, khalayak menangkap pesan yang sama seperti yang Christofer ingin sampaikan, yaitu Christofer yang menampilkan dirinya apa adanya. Christofer menggunakan berbagai tools untuk membangun hubungan dengan khalayak, Christofer dapat dijangkau melalui media sosialnya, Christofer juga membuka ruang bagi khalayaknya yang ingin menemuinya dan bahkan ia membuka rumahnya untuk komsel yang bisa didatangi setiap minggu.

- Munculnya Christofer di Media Sosial

Christofer tidak pernah berniat untuk menjadi terkenal seperti sekarang, tetapi hal itu terjadi secara tidak sengaja. Justru konten Christofer Tapiheru menjadi menonjol di media sosial karena pihak eksternal yang membagikannya di media sosial. yang awalnya hanya konten yang dibagikan kepada sesama teman Facebook, menarik perhatian banyak orang sehingga mendapat likes dan dishare ulang hingga beribu-ribu kali, dan dari situlah Christofer menjadi muncul di media sosial.

\section{KESIMPULAN}

Berdasarkan hasil penelitian dan pembahasan pada bab IV, maka peneliti dapat menarik kesimpulan bahwa gaya komunikasi Ps. Christofer Tapiheru yang adalah gaya komunikasi equalitarian style, melihat caranya berkomunikasi yang terbuka dengan feedback, dan bagaimana Christofer memposisikan dirinya dengan khalayak. Bahasa yang digunakan Christofer Tapiheru tidak terkesan seperti bahasa yang "tinggi" sehingga mudah dimengerti oleh khalayaknya.

Gaya komunikasi tersebut membentuk personal brandingnya sebagai seorang pastor yang mudah didekati oleh khalayak, Christofer selalu menampilkan dirinya secara apa adanya sehingga tidak ada setting khusus dalam menampilkan personal branding Christofer Tapiheru, Christofer hanya ingin menampilkan dirinya apa adanya. Christofer Tapiheru betul-betul tahu personal branding yang Christofer ingin tampilkan, sehingga personal brandingnya menetap dan tidak mudah dipengaruhi.

Khalayak dari Christofer Tapiheru benar-benar menangkap inti pesan dan personal branding yang ditam- 
pilkan Christofer sesuai dengan yang diinginkan Christofer, yaitu seseorang yang apa adanya.

\section{DAFTAR PUSTAKA}

AW, S. (2011). Komunikasi Interpersonal. Graha Ilmu.

Cutlip, S., Center, A., \& Broom, G. (2006). Effective Public Relations. Kencana Prenada Media Group.

Denzin, N., \& Lincoln, Y. (2009). Qualitative Research. Pustaka Pelajar.

Imawati, A, V., Solihah, A, W., Shihab, M. (2016). Analisis Personal Branding Fashion Blogger Diana Rikasari. Jurnal Ilmu Sosial dan Ilmu Politik, 5(3). Diperoleh dari https://media.neliti. com/media/publications/102746-ID-analisispersonal-branding-fashion-blogg.pdf

Liliweri, A. (2011). Komunikasi Serba Ada Serba Makna. Prenada Media Group.

Marpaung. (2017). Jadi Diri Sendiri Untuk Sentuh Hati Banyak Orang. Diperoleh dari https://www. jawaban.com/read/article/id/2017/11/20/9/17041 0170825/christofer_tapiherujadi_diri_sendiri_ untuk_sentuh_hati_banyak_orang \#
Maulana, A. (2015). Personal Branding: Membangun Citra Diri yang Cemerlang. Etnomark Consulting.

Mobray, K. (2009). The 10Ks of Personal Branding: Create a Better You. IN:iUniverse.

Montoya and Vandehey. (2008). The Brand Called You: Create a Personal Brand That Wins Attention and Grows Your Business. NY:McGraw-Hill.

Nicolino, P. (2004). The Complete Ideal's Guide: Brand Management. Prenada.

Pratiwi, B. N. (2017). Analisis Gaya Komunikasi Ahmad Faiz Zainuddin. Jurnal Ilmu Komunikasi Unmul.

Priyono, B. (2014). Strategi Menciptakan, Mempertahankan dan Menjual Personal Branding Jelang Pemilu 2014. Jurnal Visi Komunikasi, 13(2), 265-280. Diperoleh dari https://doi.org/http:// dx.doi.org/10.22441/jvk.v13i2.1658

Salam, O, D. (2020). Personal Branding Digital Natives di Era Komunikasi Media Baru (Analisis Personal Branding di Media Sosial Instagram). Jurnal Becoss, 2(1). Diperoleh dari https://journal.binus.ac.id/index.php/BECOSS/article/down load/6070/3740

Tubbs, S., \& Moss, S. (2009). Human Communication: Prinsip-Prinsip Dasar. Remaja Rosdakarya. 